\title{
ДУАЛИСТИЧЕСКИЕ СЮЖЕТЫ О СОТВОРЕНИИ ЗЕМЛИ В КОМИ ТРАДИЦИИ
}

\author{
Павел Лимеров \\ plimeroff@mail.ru
}

\begin{abstract}
Аннотация: Статья посвящена анализу легенд о сотворении мира в коми традиции. В статье рассмотрены записи коми космогонических легенд, дан историографический обзор основных работ, посвященных изучению космогонических текстов в фольклоре разных народов. Эти исследования показывают, что космогонические тексты представляют собой контаминации мотивов из мифологии уральских народов и христианских апокрифических легенд. Наиболее полная международная версия легенды состоит из четырех эпизодов-мотивов, составляющих инвариантный (канонический) сюжет космогонии. Набор эпизодов, система персонажей, сюжетные контаминации и перипетии определяются самой традицией, поэтому народные версии легенд могут существенно отличаться от канонической. В число таких версий входит коми легенда, записанная П. Г. Дорониным в 1923 году. Структурно сюжет полностью соответствует каноническому, однако, в плане содержания в его состав входят мотивы, не имеющие параллелей в подобных текстах. Прежде всего это касается сюжетного мотива сотворения суши, представляющего собой контаминацию мифологических мотивов ныряния за землей и творения мира из яйца.
\end{abstract}

Ключевые слова: легенда, космогония, язычество, христианские апокрифы, мифология, фольклор коми 


\section{История изучения космогонических легенд коми}

Первые сведения о космогонических мифрах у коми известны из «Жития Стефана Пермского» Епифания Премудрого. В главе «О пермской азбуке» он, противопоставляя христианство, имеющее «книжный разум», язычеству, как религии устной, а, значит, - неистинной, рассуждает о преимуществах христианской письменности перед пермским языческим «баснословием»:

Ибо прежде крещения перляне не видели у себя гралоть и не понилали написанного, и вовсе не знали, что такое книги. Но только баснотвориь у них были, рассказываюшие сказки о бытии и о сотворении мира, и об Адале, и о разделении народов, и о прочел повествовали, говоря больше ложь, нежели истину. Так свой век и все годь свои они и потратили. (Епираний 1995: 181)

Очевидно, что речь идёт здесь о трёх мифологических сюжетах, сходных со знакомыми Епифанию текстами из Ветхого Завета. По этим данным трудно судить о всей пермской мифологии, но сам фракт сопоставления Епифанием известных ему языческих сюжетов с ветхозаветными может свидетельствовать об их высоком нарративном уровне.

Тем не менее, до начала XX века эти сюжеты не привлекали внимания исследователей. Поэтому в обзоре космогонических легенд, предпринятом Александром Веселовским в его известной работе «Дуалистические поверья о мироздании» (1891) (Веселовский 2009: 263-362), коми версий сотворения мира нет. Первая запись космогонической легенды относится к 1895 году. Этим годом датирует текст собиратель, Иван Суворов, записавший его со слов «старушки-староверки» в д. Савинобор (Саваяг), Усть-Сысольского уезда. Текст хранится в фондах Российского этнографического музея и опубликован в «Материалах «Этнографрического бюро» князя В. Н. Тенишева» (Русские крестьяне 2008: 492-493). Героями миросотворения этой легенды являются два брата, голубь и гоголь, летавшие над первозданными водами и песком. Голубь приказывает гоголю принести песка, чтобы создать землю, гоголь пытается сотворить из этого песка свой 
мир, но голубь не допускает этого: песок стал разрастаться и душить гоголя. Гоголь молится своему брату, и тот его прощает. После этого они вместе создают землю. Однако, после того, как гоголь захотел взять верх над братом, голубь низвергает его на землю. Голубь становится Еном, небесным Богом, а гоголь - сатаной. Далее следуют эпизоды сотворения человека, согрешения первых людей и строительства вавилонской башни. Основные мотивы легенды с приведением параллелей достаточно подробно рассмотрены в статье А. С. Чувьюрова (2010: 304-321). Противопоставление голубя и гоголя, как птицы, обитающей на суше и водоплавающей птицы довольно необычно. Как правило, героями подобных текстов являются две водоплавающие птицы или птицы типа утки и гагары. Замену одной из этих птиц образом голубя можно объяснить народным отождествлением главной небесной птицы с одним из лиц христианского Бога Отца - Святым Духом в образе голубя.

Впервые описал и опубликовал ряд текстов о сотворении мира Василий П. Налимов в статье «Некоторые черты из языческого миросозерцания зырян» (1903) (Налимов 2010: 19-27). Задачи, которые он поставил перед собой, были весьма скромны: уточнить сведения о религиозном миросозерцании зырян, приведённые в статьях других авторов. Творцами мира, как пишет В. П. Налимов, являются «две верховные силы: Ен и Омӧль» (Налимов 2010: 19), при этом, Ен - создатель всего лучшего на земле: людей, солнца, звезд, лесов, рек; тогда как Омӧль - бог «мрака и тумана», он творец земноводных, насекомых, лесных людей и водяных - васа (Налимов 2010: 20). Богатства лесов и рек Ен, по просьбе Омӧля, разделил между лесными, водяными жителями и людьми. Далее, Налимов приводит версию легенды о сотворении мира двумя божествами, как он пишет, «в дословном переводе». По сюжету этой версии, два божества, занимающиеся созданием мира, первоначально имеют облик двух голубей. Они ныряют на дно "мрака и тумана», достают тину, из которой и появляется земля (Налимов 2010: 22). Данная статья была самой первой из публикаций Налимова, можно сказать, ученической, но исследователь больше не возвращался к теме космогонии даже в зрелые годы, ограничившись только этой репрезентацией своего полевого материала.

В 1920-е гг. космогонические тексты привлекают внимание Алексея Сидорова, тогда ещё молодого исследователя, живо 
интересовавшегося проблемами археологии и этнографии коми народа. В 1924 году Сидоров пишет статью «Следы тотемических представлений коми-зырян» (Сидоров 1924: 43-50), в которой различные элементы промысловой магии зырян, а также представления о животных, в том числе и некоторые фольклорные тексты, рассматриваются как пережитки некогда бытовавшей религии тотемизма. Среди этих текстов А. С. Сидоров приводит обширную цитату из космогонического сюжета о соперничестве утки и гагары:

На поверхности первозданного океана плавали гагара и лебедь. Они заспорили, чей голос из них сильнее. Гагара закричала: "Курльк-курлык” и спросила: "Испугался ли тот?” Лебедь говорит, что нет, и, в свою очередь, тихонько подала голос в отдалении. Гагара второй раз начала свой “курльк-курльк”. В ответ в отдалении посльцились раскаты грола. Сердие гагары затрепетало: почувствовало оно в голосе лебедя сверхвестественную силу. В третий раз гагара прокричала изо всей сильь. В это вреля грянул грол, и лолния ударила под сальлм бокол гагары. Она бултыхнулась, нырнула в воду, оставшись еле живой. (Сидоров 1924: 44)

Более подробный пересказ текста Сидоров предпринимает в монографиии «Знахарство, колдовство и порча у народа коми» (1928) в связи с изучением эволюции некоторых «колдовских представлений». Текст назван «общединской космогонической легендой, встречающейся и у коми», хотя параллельных этому финно-угорских текстов сам Сидоров не приводит: «Творцами мира являются два товарища (по другому варианту - два брата, причем второй брат родился от плевка первого). Один из творцов мира имеет вид лебедя, другой - гагары. Это Ен и Омӧль. Ен и Омӧль создают землю и небо (земля достаётся гагарой-Омӧлем из-под воды) и весь остальной мир» (Сидоров 1997: 238-239).

Надо отметить, что Сидоров, несмотря на большой опыт сбора фольклорных материалов, к сожалению, никогда не ставил целью их публикацию, и использовал тексты в качестве иллюстраций к своим исследовательским концепциям. Так, приведённый им текст космогонической легенды иллюстрирует разрабатываемую им в монографии тему сакральной чистотынечистоты ряда природных объектов, предметов и животных, 
обусловленную их соотнесённостью с действиями того или другого персонажа-демиурга.

Ещё один космогонический текст был использован Сидоровым в написанной в 1920-е гг. статье «Семантика изображений Пермского звериного стиля» в качестве иллюстрации к мифологическому образу гагары:

Пльл по безбрежнолу морю Ен в своей лодке-трехупружке, загребая воду двухлопастныл веслол. Плыл он долго, устал, но не видит никакого берега, куда можно было бы пристать, отдохнуть. В раздражении плюнул он на воду. Вслед за этил посмотрел он назад и видит: плььет за нил такой же человек в такой же трехупружке. Согласились, поехали влесте вперед. Спутник Ена попросил превратить его в гагару, чтобы достать со дна моря землю. Превращенный в гагару, спутник выхватил четверть зелли и стал подниматься вверх, но в это вреля поверхность моря оказалась залороженной, $и$, гагара, разбивая своей головой слой льда растрясла изо рта всю зеллю. Так же случилось и во второй и в третий раз. Напоследок она выплюнула изо рта три песчинки, из которых Ен сотворил зеллю и обитающих на ней полезньх существ, своелу же товарищу Ен дал лишь дырочку от забивания кола, из которой тот вывел всякую вредоносную для людей тварь. (Сидоров 1950: 17)

В варианте этой работы, опубликованной в 1972 году (Сидоров 1972: 10-23), данный текст приведён в более кратком переложении, с указанием, что он был записан А. С. Сидоровым в 1913 году (Сидоров 1972: 13). В этой же работе даётся краткий пересказ другого космогонического сюжета, главным персонажем которого является утка-«праматерь». Утка сносит шесть яиц, «заключавших в себе зародыш будущего мира», четыре из них утонули в морской пучине, а из двух последних вылупились птенцы, ставшие демиургами Еном и Омӧлем. Братья достают со дна моря яйца, «которые, будучи разбитыми о тело утки чӧж дают начало солнцу, луне, добрым и злым духам, а само тело утки чӧж разрастается в длину и ширину, покрывается лесами, зеленью и цветами». Так создаётся земля, которой Ен и Омӧль, действуя наперекор друг другу, придают современный вид (Сидоров 1972: 14). 
Данный мифологический текст Сидоров приводит в связи с реконструкцией образа «прародительницы общества, построенного на матриархальных началах». По мнению исследователя, в этой легенде ярко отражены мифологические представления о том, что в основе «не только человеческого общества, но и самой природы лежит материнское (женское) начало (Сидоров 1972: 14). Археологические находки бронзовых уточек, имеющие соответствие в изображениях деревянной пластики народной культуры, дают основание для предположения о том, что утка «являлась объектом тотемистического культа», а сам образ птицы был олицетворением солнца, неба, прародительницы рода (Сидоров 1972: 14). Изучая предметы Пермского звериного стиля, Сидоров отмечает семантическое сходство образов птицы и лося, в ряде случаев выступающих в одних и тех же сюжетных мотивах, и делает вывод о том, что «лось, как и птица, представляется на изображениях матерью солнца, прародительницей мира и людей, т. е. в зооморфном образе женщины» (Сидоров 1972: 15). Эти исследовательские находки Сидорова оказали существенное влияние на последующие штудии семантики образов бронзовой пластики.

Что касается текста об утке-прародительнице, то полный его вариант находится среди архивных материалов Павла Доронина с указанием, что он переписан с переводом в 1923 г. в дер. Проньдор (Прокопьевка) П. Г. Дорониным из рукописного списка на коми языке, принадлежавшем И. С. Доронину. Данный текст представляет развёрнутую версию космогонии, включающую сотворение всех уровней мироздания и создание человека, и характерен ярко выраженной концепцией антагонизма братьев-демиургов. Таким образом, все известные на сегодняшний день тексты о миросотворении относятся к типу легенд, которые принято считать дуалистическими. Цель нашего исследования - выявить детали сюжета, делающие его дуалистическим, и охарактеризовать их.

\section{Образность дуалистических легенд коми}

Проблема происхождения дуалистических легенд стала объектом внимания российской фольклористики в середине XIX века. Известный исследователь мифологии Александр Афанасьев 
объяснял их как древние дохристианские мифы славян (Афанасьев 1865: 92). В то же время высказывалось мнение об отсутствии на славянской почве самой идеи дуализма, соответственно, происхождение этих легенд объяснялось влиянием на языческий субстрат южнославянских гностико-богомильских учений. ${ }^{1}$ К примеру, известный историк Афанасий Щапов по этому поводу писал, что в начальный период христианизации Руси в Византии и в Болгарии скопилось достаточно много апокрифической литературы гностических толков: павликиан, богомилов, манихеев, мессалиан - со временем перешедших к русским книжникам. «В XIII-XIV вв. эти книги оказали такое сильное влияние на народную мыслительность, что грамотники народные сами сочиняли апокрифические статьи, с примесью мифологических элементов» (Щапов 1861: 280).

Таким образом, на первый план была выдвинута концепция сложной природы дуалистических легенд, включавших в свой состав наряду с устным славянским языческим компонентом книжный, христианский апокрифический компонент. Однако уже в конце XIX века некоторые исследователи ставили под сомнение богомильские истоки космогонических легенд. К примеру, А. Н. Веселовский, рассмотрев корпус дуалистических легенд как русских, так и «инородцев», пришёл к выводу об их урало-алтайском происхождении (Веселовский 2009: 263). Контаминации христианских и языческих, славянских и «финно-тюркских» компонентов легенд он объяснял тем, что «черемисская, мордовская и т. д. и южнославянская легенды принадлежали первично одной и той же полосе развития и религиозного миросозерцания, богомилы лишь внесли в круг своих дуалистических мифов, может быть, не славянское предание, отвечающее их целям, а черемисы и алтайцы получили обратно свой старый космогонический миф в освещении христианской ереси и апокрифов. Следы их влияния настолько ясны, что на их указании останавливаться не стоит. Отметим лишь в одной из мордовских легенд эпизод о “рукописании Адама», о древе познания, о вине, как изобретении дьявола (морд., вотяцк., монгол.) и т. д. Так или иначе, исконно-славянский характер дуалистического мифа о мироздании должен быть оставлен под сильным сомнением» (Веселовский 2009: 282). Эта гипотеза никак не поставила точку в решении проблемы генезиса дуалистических легенд, напротив, уже в следующей своей статье, 
Веселовский привёл ряд параллелей к рассмотренным космогоническим версиям из мифологий других народов, в частности, американских индейцев (Веселовский 2009: 362-403), связь которых с болгарскими богомилами обнаружить было бы крайне затруднительно.

В последние годы проблема происхождения дуалистических легенд разрабатывалась Владимиром Напольских в связи с реконструкцией прауральского мифа о возникновении земли (Напольских 1991: 189). Для своего исследования он ограничился эпизодом ныряния за землёй, который, будучи сюжетообразующим для всего текста о сотворении мира, является трансформацией инвариантного мифа о ныряющей птице (МНП). Наиболее архаичной (прауральской) Напольских признаёт форму мифра МНП-2, по сюжету которого две птицы - утка и гагара по очереди ныряют на дно океана за землёй. Первой ныряет гагара, однако ей не удается достигнуть дна, затем ныряет утка, которой в силу её божественной сущности, удаётся достать со дна океана комочек ила или несколько песчинок, затем вырастающих в сушу (Напольских 1991: 47). Вследствие деградации сюжета в МНП-1, ныряющим и достающим землю персонажем становится утка (гагара, часто дьявол) ныряющая на дно океана по приказу демиурга (Напольских 1991:47-48). Проблему американских параллелей к мифу о нырянии Напольских решает с помощью гипотезы об общем для Евразии и Северной Америки сюжете МНП-0, в котором задачу добывания земли не могут выполнить несколько птиц, кроме последней, самой слабой фризически, но обладающей божественной силой птицы (Напольских 1991: 59).

Выводы Напольских подтверждаются исследованием Веры Кузнецовой, ставившей целью выяснить соотношение христианских и этнических элементов в славянской космогонической легенде (Кузнецова 1998: 22). По её мнению, сюжет славянской космогонической легенды представляет собой сложное образование, включающее в свой состав четыре основных эпизода, которые могут выступать и как вполне самостоятельные сюжеты: «I - о творении земли, II - о творении ангелов и демонов, III - о соперничестве творцов и свержении Сатаны с небес, IV - о происхождении первого человека» (Кузнецова 1998: 53). Первый эпизод-сюжет - это собственно мифр о ныряющей птице, «органично перенятый русью» от соседних фринно-угорских племен, в то время как другие эпизоды сложились на основе 
книжных, преимущественно христианско-апокрифических мотивов (Кузнецова 1998: 132). Сравнивая легенды восточнои южнославянской устной и книжной традиций, Кузнецова приходит к выводу о северорусском происхождении сюжета о дуалистическом миросотворении, «как определенного набора контаминированных сюжетов-мотивов с рассказом о нырянии за землей на дно первичных вод в качестве организующего центра» (Кузнецова 1998: 135). То есть, ни о каком болгарско-богомильском влиянии на дуалистический сюжет речи не может быть. В то же время эпизод ныряния за землёй, усвоенный севернорусской традицией, имеет корни в религиозно-мифологической системе финно-угров.

По мнению В. В. Напольских, МНП был «вписан» в картину мира, которую исследователь реконструирует как прафинноугорскую и прауральскую: «юг ассоциируется с небом, верхним миром, страной богов, там же находится страна водоплавающих птиц (утка); север - нижний мир, вода, море, устье реки, мир мертвых и злых духов; юг и север соединяются по земле рекой, берущей начало в верхнем мире и впадающей на севере в море нижнего мира, а по небу - Млечным путем - «дорогой водоплавающих птиц» (Напольских 1991: 74). Коми тексты занимают среднее положение между западносибирскими и восточноевропейскими версиями МНП: «в них уже присутствует новая дуалистическая идея (противостояние бога и черта), но сохраняется и старый дуализм более низкого уровня - противостояние утки или лебедя и гагары - как в МНП-2» (Напольских 1991:53). Иными словами, коми версии космогонических текстов являются тем пределом, за которым эти тексты эволюционируют в другую форму (МНП-1) и приобретают некие иные смыслы.

Нас интересует как раз версия дуализма, названная Напольских «старым дуализмом более низкого уровня». Всё-таки, вся последующая дуалистическая концепция с противостоянием Бога и Чёрта (Бога и Сатаны), широко представленная в фольклоре разных народов, впервые заявлена в сюжете МНП в антагонизме двух водоплавающих птиц. Для анализа привлекается легенда, записанная П. Г. Дорониным в 1923 году. Эта легенда имеет ряд характерных особенностей, не имеющих аналогов в других подобных текстах. Эти особенности относятся, прежде всего, к различным деталям сюжета, набору мотивов, вместе с тем, это ниболее полный вариант космогонического текста, 
имеющий в своём составе все эпизоды-мотивы, выделенные В. С. Кузнецовой.

Оригинальность сюжету придаёт участие в нём трёх, а не двух водоплавающих птиц - в зачине сюжета появляется утка мать будущих создателей мира:

По беспредельному первозданнолу морю-океану плавала утка чӧж, носившая в себе яйиа жизнезарождения. Она долго искала места, где бы ей высидеть своих птениов, но так и не нашла себе пристанища. Четыре яйиа, снесённые ею, были поглощены пучиной морской, только два последних яйиа она сулела спасти. Высиженные под крылол матери, из двух яиц вылупились два птениа, два утёнка: Ен и Олӧль. Это были два брата, два противоположных начала: жизни и слерти, добра и зла, правды и неправды, дня и ночи. Долго мать носила их на своей спине, потол попросила утят достать из пучинь морской упавшие яйца и разбить их на её теле. После этого сала взлетнулась ввысь, калнел бросилась вниз и разбилась о поверхность водьь. (Лимеров 2005: 17-18)

Далее следует эпизод ныряния утят на дно океана за утонувшими яйцами, в процессе которого уже проявляется антагонизм братьев: первым ныряет Ен, и пока он находился на морском дне, «Омӧль засвистел, закричал таким голосом, что от этого крика всё застыло и поверхность океана вся заледенела». Ен выходит из пучины, разбив лёд молниями. Достав яйца со дна моря, братья разбивают их о тело матери-утки. Из яиц, разбитых Еном, загорается солнце, тело матери-утки разрастается в длину и в ширину, покрывается зеленью, лесами и становится «землёй-матушкой», появляются ангелы, а от яиц, разбитых Омӧлем, загорается луна, на земле появляются озёра и болота, зыбуны, рождаются демоны. Выйдя на сушу, братья принимают человеческий облик, Ен создаёт полезных птиц и животных, Омӧль - хищников и пресмыкающихся, затем создают первых людей - мужчину и женщину. (Лимеров 2005: 18-20)

В финно-угорской мифологии выделяются два сюжета сотворения мира: 1. землю достаёт со дна первичного океана водоплавающая птица (мифр о ныряющей птице, далее-МНП); 2. земля и другие элементы космоса создаются из яйца птицы 
(мифр творения из яйца, далее - МТЯ). Последний сюжет преимущественно распространён среди западных финнов - карел, финнов, эстонцев, саамов и др., тогда как среди восточных финнов - коми, удмуртов, мордвы и мари имел хождение МНП (Айхенвальд \& Петрухин \& Хелимский 1998: 564).

Рассматриваемая легенда представляет собой контаминацию сюжетов МНП и МТЯ: утка сносит яйца, но мир создают два персонажа, ныряющие за яйцами на дно океана. Общим для двух совершенно разных сюжетов творения является отсутствие в первозданном океане опоры, от которой полагается начало творения. Изначально опора отсутствует в сюжете МНП, в котором земля (ил) достаётся со дна океана, тогда как в западно-фринских МТЯ такая опора есть: птица вьёт гнездо на колене Вяйнемёйнена (карело-фин.); на золотом кусте среди моря (эст.); на кочке среди первичных вод (ижорск.). Яйцо скатывается в море, разбивается, и из его частей возникают небо, земля, небесные светила (Напольских 1991: 29). Реконструкция прибалтийско-финской праформы МТЯ такова: «небесная птица летает над морем, ищет места для гнезда и, найдя (кочку), откладывает три яйца; поднимается ветер, яйца падают в воду, из них рождаются солнце, луна, звезды (возможно также земля и небо) (Напольских 1991: 30). Как видим, западнофинский вариант текста не содержит мотива ныряния птиц за яйцом, птица сносит яйцо не на воду, а на колено первочеловека, кочку, золотой куст или другой аналог мировой оси (горы, мирового древа), яйцо разбивается само - от падения, а не потому, что его разбивает персонаж легенды. Иными словами, сюжет МТЯ требует обязательного включения в текст такого значимого элемента как мировая опора для космического яйца, поэтому в нём даже не нужен образ водоплавающей птицы, обязательный для МНП, и этот прауральский архаизм утрачивается в эстонских и ижорских сюжетах. В этом смысле прибалтийско-дринские и коми МТЯ представляют собой совершенно разные сюжеты, и главным мотивом последнего всё-таки является мотив ныряния, к которому присоединён мотив птицы, откладывающей яйца прямо в воду.

Последний мотив (откладывание яиц в воду) довольно необычен для подобных текстов и в космогониях встречается редко. Помимо коми-зырян, он фиксируется в легенде коми-пермяков: 
Весь мир представлял собой безбрежный океан, в которол плавала утка. Она снесла яйио и уронила в воду. Гагара нырнула на дно океана, достала яйио и разбила его. Верхняя половина яйиа превратилась в небо, а нижняя - в землю. (Конаков 1996: 18)

Легенда с подобным мотивом встречается в марийской традиции:

На лоно первичного океана ... прилетела утка. Снеся два яйиа, она их высидела под своили крыльяли. Из этих яии родились два брата-селезня - Юло и Йьн. Зател они попереленно, нырнув под воду, в клюве со дна океана достали зеллю. Из той зелли, что достал Юло, образовалась ровная поверхность. Йьн же поперхнулся и влесте с зеллей выплюнул и слюну. Поэтолу на зелле возникли горы, озера и болота. (Калиев 2004: 108)

Оба текста также представляют собой контаминации МТЯ и МНП, вместе с тем в них имеются существенные отличия от коми-зырянского сюжета. Если в коми-зырянском сюжете первичным материалом для мира оказывается тело утки-праматери, то в коми-пермяцком само яйцо (МТЯ), а в марийском земля со дна океана (МНП). ${ }^{2}$ Отсутствие опоры для кладки яиц компенсируется в коми-пермяцком тексте тем, что гагара сама разбивает космическое яйцо, тогда как в коми-зырянском и марийском текстах утка высиживает яйца под своими крыльями. ${ }^{3}$ По справедливому замечанию Николая Конакова, изначальной версией для коми-зырянского сюжета был мотив добывания ныряющей птицей земли, к которому присоединён мотив творения из яйца (Конаков 1996: 17). Очевидно, что МНП в составе сюжета не предполагает в первоначальном океане наличия космической опоры, первозданные воды должны быть пустынны, соответственно, в контаминированный сюжет включается мотив откладывания яиц на воду. Однако, этот мотив не характерен ни для сюжетов МТЯ, ни, тем более, для сюжетов МНП, поэтому есть основания предположить его книжное происхождение. Книжные параллели этому мотиву обнаруживаются в легендах о мифической птице алконост (алкион), восходящих к «Шестодневу» Иоанна Экзарха Болгарского и «Толковой Палее». Согласно этим легендам, алконост (алкион) откладывает 
яйца в глубину моря: «Алконост яйца своя в глубину кладёт, сама вверху воды наседит» (Белова 2001: 53; Белова \& Петрухин 2008: 177-179). Влияние книжного сюжета на фольклорный очевидно, при этом на утку переносятся признаки птицы алконост - откладывать яйца на глубину и высиживать птенцов в море, а проблема извлечения затонувших яиц решается традиционным мотивом ныряния.

Для коми-зырянского сюжета мотив самоубийства уткипрародительницы необходим, поскольку является условием для включения в действие главных персонажей - Ена и Омӧля (Бога и Чёрта). Архетипическая модель дуалистического мифа, лежащая в основе текста, требует возвращения к двухперсонажной схеме сюжета. Далее по сюжету следует характеристика демиургов: «это были два брата, два противоположных начала: жизни и смерти, добра и зла, правды и неправды, дня и ночи» (Лимеров 2005: 18). Такое описание персонажей несколько искусственно для устного текста, но в данном случае мы имеем дело с текстом из рукописи, и, возможно, первоначальный сюжет подвергался определённой обработке составителем рукописного сборника. Тем не менее, для данного текста эта характеристика очень важна, поскольку она раскрывает дуализм персонажейдемиургов. На композиционном уровне она выступает в качестве главного фрактора смысловой организации дальнейшей структуры повествования. Противопоставленность братьев выражена уже в их именах как оппозиция "верха» и «низа». Теоним Ен [енм-] соответствует значениям 'бог', 'небо'; jen - jenm 'бог' доперм.; jen коми-зыр., коми-перм., коми-язьв. / удм. ин - инл ‘небо', инмар ‘бог'. - Общепермск. ;“زеnm- 'бог', 'небо' // финск. ilma 'воздух погода'; Ilmarinen 'бог воздуха' (мифол.) = доперм. *ilma- 'воздух, небо' (Лыткин \& Гуляев 1999: 99). Теоним Олӧль в коми языке имеет значения 'плохой, скверный, худой, гадкий' (Коми-русский 1961: 489), таким образом, он как бы противопоставлен Ену как «плохой бог» «хорошему».

Представляет интерес предположение Н. Д. Конакова о лингвогенетической связи термина олӧль со словами олла, оллӧд, оллӧг, означающими 'речной залив, заводь, омут, глубокое место в реке, провал, яма на дне реки', а также энь олла в значении 'женская матка' (Конаков 1996: 11; Лыткин \& Гуляев 1999: 205). На связь со стихией воды указывает и одна из версий происхождения Омӧля из плевка Ена (Кузнецова 1998: 
63). Семантические и лингвистические аналоги этим терминам обнаруживаются в мифологии карел и финнов. Так, по материалам Эйно Карху, Ильларинен - финск. ilma - 'воздух, воздушное пространство, небосвод, погода' - небесный богдемиург прафинно-угорского происхождения. Вяйнелёйнен финск. väinä 'широкая река со спокойным течением'; ливск. venä 'устье, пролив'; эст. väin, vein 'устье, пролив' (Карху 1994: 75-76). Ср.: коми оллӧд - общеп. *ођз-lз- 'яма, борозда, провал, углубление'; доперм. * ӑэa- 'углубление, проём' (Лыткин \& Гуляев 1999: 205). Соотнесение терминов оллӧд 'омут' и энь олла 'матка' может быть объяснено сходством признаков «глубокого места с водой» и «глубины» - символического «низа» с женским началом. Н. Д. Конаков совершенно справедливо проводит параллель между коми олла и древнетюркским улай в значении 'богиня-покровительница деторождения, а также послед, утроба, матка' (Конаков 1996: 11). Так или иначе, эти слова не только фонетически близки, они связаны и общей семантикой плодородия, порождения, поскольку рождение ребёнка из материнского чрева в мифологии приравнивается к рождению мира из первоначального хаоса. Однако, как отмечает Сергей Аверинцев, в качестве хаоса вода является принципом всеобщего зачатия и порождения и содержит в себе женское и мужское начала: «В роли женского начала вода выступает как аналог материнского лона и чрева... одновременно вода - плодотворящее мужское семя, заставляющее землю рожать» (Аверинцев 1998: 240). Таким образом, термины олӧль-олла представляют собой пару мужского и женского в связи с мифологическим низом.

Здесь уместно вспомнить гипотезу Фёдора Плесовского, по мнению которого, происхождение термина Олӧль связано с термином Йола, обозначающим женское божество периода матриархата, трансформировавшимся в период патриархата в мужское божество. По его мнению, термин Йола-Олӧль является заимствованным инвертированным наименованием западнофинского божества Юлал, Юлала (Плесовский 1972: 38). Н. Д. Конаков также считает термин олӧль «лингвистическим аналогом» теонима западных финнов - Юлала, Юлал. По его мнению, вследствие запрета на произношение имени злого бога иноязычный теоним высшего фринского божества был использован коми в качестве эвфемизма для обозначения своего «тёмного» бога (Конаков 1996: 10-11). Женская ипостась 
этого «тёмного» божества угадывается в имени сказочного персонажа Йола (Ёла), имеющем аналоги в прибалтийскофинских языках: коми ёла 'ведьма, баба-яга'; јота зырянск. (juma в удорском диалекте коми языка). Коми < приб.-финск., cp. фринск. jumala 'бог', диал. maajumala 'колдунья, ведьма' (Лыткин \& Гуляев 1999: 100). Представляется всё же, что дело здесь не в заимствовании из прибалтийско-финских языков, поскольку коми термины олӧль, йома, как и финские юлала, юлал, имеют индоевропейские лингвистические параллели.

Если отвлечься от концепции первичности матриархата, то в предположении Ф. В. Плесовского о разделении мужской и женской ипостасей единого божества угадывается космогоническая идея разделения первоначального андрогина на мужскую и женскую половины. Здесь с необходимостью возникают параллели с персонажами индоевропейских мифологий: Илир, первопредок в скандинавской мифологии (слово Ymir этимологически означает двойное, т. е. двуполое существо или близнеца; ср.: ирландское emnin 'близнец'; латышское jumis 'двойной плод’ (Мелетинский 1998: 510). В свою очередь, Ymir генетически связан с такими персонажами индоиранской мифологии, как Ялма и Яли («Ригведа»), Йила и Йимак («Бундахишна») - пары первых людей-прародителей человечества. Имена этих персонажей этимологически толкуются как 'близнец', 'двойник' (Лелеков 1998: 599). В свете этих типологических соответствий, Йома является близнечной парой Олӧля, и, возможно, это теоним женского божества плодородия, эквивалентного образу Богини-матери (ср. тюрк. Улай). Сам термин олӧль через допермское *ӑұа- 'углубление, проём' (Лыткин \& Гуляев 1999: 205) может восходить к общефинскому значению женского лона как мифического всепорождающего начала, хаоса. Иными словами, если имя первого демиурга Ен связано с понятием «неба» и «верха» «света», т. е. «верхнего мира», то второй демиург Омӧль изначально связан с понятием "воды», «тьмы», «женского лона», что семантически тождественно «низу», «нижнему миру». В свете этого, можно сказать, что термин Омӧль обозначающий «тёмного» демиурга, может быть первичным по отношению к слову олӧль 'плохой' и изначальным теонимом наряду с теонимом Куль.

Герои космогонии считаются братьями, нередко - близнецами, так что сюжет легенды изначально уравнивает права каж- 
дого в будущем универсуме. Н. Д. Конаков видит в изначальной нейтральности демиургов идею первичной неразделённости хаоса: как только начинает создаваться мир, братья превращаются в антиподов (Конаков 1996: 12). Тем не менее, в аналогичных легендах других народов образы ныряющих птиц варьируются: как правило, это утка (гусь, лебедь) и гагара, и данное различие образов ныряльщиков восходит к первоначальным формам текста - прауральскому мифу (Напольских 1991: 62-63).

По ходу ныряния за утонувшими яйцами братья впервые показывают себя как соперники. Эпизод ныряния включает оригинальный мотив диффреренциации противников по акустическим признакам: пока нырнувший Ен находится на «дне морском», Омӧль свистит и кричит, отчего поверхность океана покрывается льдом; в ответ Ен отвечает громом и молнией. Мотив свиста и грома в МНП не имеет параллелей ни в одной традиции, хотя этнографическим соответствием ему могут быть представления коми о противопоставленности этих двух стихий: свист ассоциируется с нечистой силой, нечистыми (заложными) покойниками, с северным ветром, тогда как гром - с Богом, Ильёй-пророком. Анатолий Панюков полагает, что в данном случае мы имеем дело с одним из первых космогонических актов - «озвучиванием хаоса» (Панюков 2006: 129). Иными словами, космос впервые созидается как звуковая структура, причём в этой структуре звуки изначально диффреренцированы иерархически: «замораживающий свист», издаваемый Омӧлем, оказывается иерархически ниже, чем звук грома, производимый Еном. В одном из космогонических текстов коми гагара-Омӧль подаёт голос: «курлык-курлык» в надежде, что лебедь-Ен испугается, на это Ен отвечает грохотом грома и молниями (Лимеров 2005: 17). Свист и гром оказываются противопоставленными друг другу как проявления разной степени демиургической силы братьев, причём «замораживающий свист» Омӧля в буквальном смысле подавляется молниями и громом Ена. ${ }^{4}$ Таким образом, в структуру создающегося мира онтологически закладывается принцип божественного подавления хаотических проявлений, исходящих от «тёмного» сотворца. В свете этого становится более понятным механизм эвфемизации наименования тёмного начала на основе отмеченной Н. Д. Конаковым семантической пары ён 'сильный, крепкий' - олӧль 'худой, плохой, слабый' (Конаков 1996: 10). ${ }^{5}$ 
Следует отметить, что мотив «замораживания поверхности воды» также известен в коми традиции по тексту, записанному в 1913 году А. С. Сидоровым: Чёрт, превращённый Богом в гагару ныряет за землёй, но, когда он поднимается со дна моря, его поверхность оказывается покрытой льдом (Лимеров 2005: 25). В тексте не говорится о том, что именно Бог замораживает поверхность воды, но это подразумевается. Возможно, в данном случае мы имеем дело с редуцированным вариантом сюжета южнославянской космогонической легенды о похищении у Сатаны ценного предмета: «Бог отправляет ангела отнять у Сатаны ценный предмет. Посланный хитростью побуждает Сатану нырнуть на дно моря, завладевает ценным предметом, оставленным на берегу, и устремляется на небо; Бог, чтобы помешать погоне, покрывает воду льдом, но Сатана пробивает его, преследует, почти настигает похитителя, но ему не удается вернуть похищенное» (Кузнецова 1998: 70). Что касается рассматриваемого сюжета, то при всей схожести, мотивы «замораживания» в этом и южнославянских текстах имеют различную семантику. Если в нашей легенде свист и лёд органично связаны с образом "тёмного демиурга» и эксплицируют его стремление взять верх над «светлым» братом, то славянский мотив, как отмечает А. Н. Веселовский, восходит к богомильским вариантам сюжета, в которых Сатана создает венец-солнце, а Бог его похищает (Веселовский 2009: 313).

Из шести яиц, снесённых уткой, два содержат в себе демиургов-антагонистов, а остальные четыре - энергии созидания и разрушения. Поэтому здесь важен сам мотив разбивания как освобождение соответствующих энергий. Освобождённые светлым демиургом энергии качественно преображают первоначальный космический материал - тело утки, и оно становится землёй-сушей, покрывается лесами и зеленью, вверху загорается солнце, а тёмный демиург освобождает отрицательные энергии, и в небе появляется луна, а на земле - признаки смертности всего, что было вызвано к жизни первым демиургом - «по земле потекли безжизненные потоки воды, зазияли озера, болота и зыбуны» (Лимеров 2005: 18). Как только обозначилась земля, на смену первоначальному единству океана приходит двоичное сочетание воды и суши. Далее начинается строительство дуального космоса, первопричиной которого является антагонизм мифологических персонажей. Фактиче- 
ски все известные тексты легенд сходятся в том, что «тёмный» демиург (Чёрт) портит созданное его «светлым» братом (Богом), и с этим связывается несовершенство мира. Как правило, начало активного противостояния творцов вводится в сюжет мотивом «утаивания земли»: Сатана оставляет во рту часть вынесенной со дна океана земли и выплёвывает её на созданную Богом землю - отчего на гладкой поверхности земли появляются горы, овраги, озёра и т. п. (Кузнецова 1998: 71). ${ }^{6}$ В коми легендах этого мотива нет, «порча» созданного Еном-Богом объясняется изначальным «злонравием» Омӧля-Черта. Собственно, порча рельефа земли есть только в рассматриваемом тексте, но она связана с высвобождением Омӧлем негативных сил, заложенных в космическом яйце. Точно также творение ангелов и демонов представлено высвобождением их из яйца, а не традиционным мотивом высекания их из камня.

Таким образом, дуализм не характерен для сюжетов о творении мира из яйца. Важной деталью, отличающей МТЯ является отсутствие в его сюжете конфликтной ситуации, характерной для дуалистических легенд. Поэтому сюжеты МТЯ, как правило, завершаются моментом создания мира и не имеют перспективы событийного развития: мир создан и всё то, что происходит в этом мире в дальнейшем - мало соотносится с персонажами МТЯ. Коми вариант легенды о творении мира из яйца является контаминацией сюжетов МТЯ и МНП и, в силу этого, сохраняет дуализм последнего. Версия откладывания водоплавающей птицей яиц в воду книжного происхождения и связана с образом птицы алконост. В тексте МНП (космогонической легенды) дуализм включён в структуру сюжета: само развёртывание сюжета сотворения мира возможно только благодаря наличию дуализма двух персонажей, перерастающего в конфликт. Это кондрликт двух персонажей с противоположными ролями «сильного и слабого», «плохого и хорошего». Дуализм обнаруживается и на лингвосемантическом уровне и выходит за рамки собственно коми мифологической образности. Далее, этот конфрликт развёртывается в сюжет противостояния Бога и Чёрта, который происходит уже после создания мира, в только что созданном пространстве и времени, с привлечением других персонажей, другого событийного ряда. Отсюда недалеко и до сюжетных 
коллизий литературных произведений: уже указанные ролевые противопоставления персонажей мифологического сюжета, по сути, дают начало пониманию сюжетной деятельности героев как реализации их личностной судьбы. Это уже аспект развития нарративного сознания рассказчика, и он позволяет включать в состав повествования бесконечное число эпизодов, не противоречащих основной схеме коллизии - противопоставлению «плохого и хорошего», впервые заявленной в дуализме утки и гагары.

\section{Примечания}

1 Более подробно об этом вопросе см. Кузнецова 1998: 3-28.

2 В. В. Напольских в качестве параллели к мотиву возникновения земли из тела утки приводит вариант латышского МТЯ: Бог разрывает на части орла, и из его крови образуется море, из тела - грязь и ил, найденное внутри орла яйцо Бог разламывает, и из его верхней части образуется небо, а из нижней, упавшей в море и смешавшейся с илом - земля (Напольских 1991: 32).

${ }^{3}$ Н. Д. Конаков трактует этот мотив как версию «чудесного рождения»: таким образом, в мифологических традициях рождались волшебные существа, в коми традиции Богородица родила Иисуса Христа из правой подмышки руки (Конаков 1996: 17). Эту версию поддерживает и Ю. Калиев (Калиев 2004: 109).

${ }^{4}$ Ср. в русской легенде: «По мановению жезла Господня появилось небесное воинство, по свисту Сатанаила - сонмы демонов» (Кузнецова 1998: 347).

5 Н. Д. Конаков вполне правомерно полагает, что термин «Куль» имеет большие основания быть исконным наименованием тёмного божества, тогда как «Омӧль» - эвфемизм.

6 В. В. Напольских считает появление этого мотива в финно-угорских и тюркских текстах влиянием народно-христианской, возможно русской, традиции (Напольских 1991: 138). 


\section{Литература}

Аверинцев, Сергей 1998. Вода. - Токарев, Сергей (ред.). Мифбы народов мира. Энииклопедия. Т. 1. Москва: Большая Российская энциклопедия, 240.

Айхенвальд, Александр \& Петрухин, Владимир \& Хелимский, Евгений 1998. Финно-угорская мифология. - Токарев, Сергей (ред.). Мифбы народов мира. Энииклопедия. Т. 1. Москва: Большая Российская энциклопедия, 563-568.

Афанасьев, Александр 1865. Поэтические воззрения славян на природy. T. 1.

Белова, Ольга 2001. Славянский бестиарий. Словарь названий и силволики. Москва: Индрик.

Белова, Ольга \& Петрухин, Владимир 2008. Фольклор и книжность. Мифб и исторические реалии. Москва: Наука.

Веселовский, Александр 2009. Дуалистические поверья о мироздании. Левит, Сергей (ред.). Веселовский, Александр. Избранное: Традииионная духовная культура. Москва: Российская политическая энциклопедия, 263-362.

Епифаний, Премудрый 1995. Преподобного в священноиноках отца нашего Епифания Слово о житии и учении святого отца нашего Стефана, бывшего в Перми епископом. - Прохоров, Гелиан (ред.). Святитель Стеббан Перлский. Санкт-Петербург: Глаголъ, 50-266.

Калиев, Юрий 2004. Этнокультурный статус мифбологического сознания: генезис, бункционирование и эволюиия традиционного мировосприятия (на примере марийской мифбологии). Уфа: РИО БашГУ, 326.

Карху, Эйно 1994. Карельский и ингерланландский фбольклор в историческол освещении. Санкт-Петербург: Наука.

Конаков, Николай 1996. Традиционное мировоззрение народов коми: окружающий мир. Пространство и время. Сыктывкар: Издательство КНЦ УрО РАН.

Коми-русский словарь. Москва,1961. 
Кузнецова, Вера 1998. Дуалистические легенды о сотворении мира в восточнославянской фольклорной традиции. Новосибирск: Издательство СО РАН.

Лелеков, Леонид 1998. Йима. - Токарев, Сергей (ред.). Мифбы народов мира. Энциклопедия. Т. 2. Москва: Большая Российская энциклопедия, 599.

Лимеров, Павел 2002. Сюжеты о сотворении земли в коми фольклорной традиции. - Лимеров, Павел (ред.). Фольклористика коли. Сыктывкар: Издательство КНЦ УрО РАН, 4-16.

Лимеров, Павел (сост., ред.) 2005. Му пуксьӧм - Сотворение мира. Мифбология народа коми. Сыктывкар: Коми книжное издательство.

Лыткин, Василий \& Гуляев, Евгений 1999. Краткий этимологический словарь коми языка. Сыктывкар: Коми книжное издательство.

Мелетинский, Елеазар 1998. Имир. - Токарев, Сергей (ред.). Мифбы народов мира. Энииклопедия. Т. 1. Москва: Большая Российская энциклопедия, 510.

Налимов, Василий П. 2010. Некоторые черты из языческого миросозерцания зырян. - Загребин, Александр \& Шарапов, Валерий (сост.). Налимов, Василий. Очерки по этнографбии фбинно-угорских народов. Ижевск-Сыктывкар: Удмуртский ИИЯЛ УрО РАН, ИЯЛИ Коми НЦ УрО РАН, 19-27.

Напольских, Владимир 1991. Древнейшие этапы происхождения уральской языковой семьи: данные мифологической реконструкции. (Прауральский космогонический миф) - Миссонова, Лариса (ред.). Народы уральской языковой семьи. Вып. 5. Москва: Институт антропологии и этнографии АН СССР.

Панюков, Анатолий 2006. Маргиналии коми музыкальной культуры: Мир птиц. - Народная культура Европейского Севера России: региональные аспекты изучения. Сыктывкар: Издательство Сыктывкарского государственного университета, 126-150.

Плесовский, Фёдор 1972. Космогонические мифы коми и удмуртов. Безносиков, Яков \& Микушев, Анатолий (ред.). Этнография и фбольклор коли .Труды Института языка, литературы и истории. Вып. 13. Сыктывкар: Издательство Коми филиала АН СССР, 32-46. 
Русские крестьяне 2008 = Русские крестьяне. Жизнь. Быт. Нравы. Материаль «Этнографического бюро» князя В. Н. Тенишева. Т. 5. Вологодская губерния. Ч. 4. Тотемский, Устьсысольский, Устюгский и Яренский уезды. Санкт-Петербург.

Сидоров, Алексей 1924. Следы тотемических представлений в мировоззрении зырян. - Коли му. № 1-2. Сыктывкар, 43-50.

Сидоров, Алексей 1950. Семантика перлского звериного стиля. Научный архив Коми НЦ УрО РАН. Ф.1. Оп.13. Д.16. (рукопись).

Сидоров, Алексей 1972. Идеология древнего населения Коми Края. Безносиков, Яков \& Микушев, Анатолий (ред). Этнография и фбольклор коли Труды Института языка, литературы и истории. Вып. 13. Сыктывкар: Издательство Коми фрилиала АН СССР, 10-24.

Сидоров, Алексей 1997. Знахарство, колдовство и порча у народа коми. Санкт-Петербург: Алетейя.

Щапов, Афанасий 1861. Смесь христианства с язычеством и ересями в древнерусских народных сказаниях о мире. - Русский палолник. Ч. I, 241-283. 


\section{ФОЛЬКЛОРИСТИКА КОМИ: исследования и материалы}

\section{http://www.folklore.ee/rl/pubte/ee/sator/sator17/}

ISSN 1736-0323

ISBN 978-9949-586-24-0

DOI: $10.7592 /$ Sator.2016.17

Тарту 2016

Авторы: Ирина Ильина, Юлия Крашенинникова, Павел Лимеров, Людмила Лобанова, Светлана Низовцева, Алексей Рассыхаев, Анатолий Панюков, Галина Савельева,

Олег Уляшев

Редактор серии: Маре Кыйва

Редакторы-составители выпуска: Людмила Лобанова \& Николай Кузнецов

Оформление обложки: Анатолий Панюков \& Андрес Куперьянов

Верстка \& HTML: Диана Кахре

Печатное издание: ФОЛЬКЛОРИСТИКА КОМИ: исследования и материалы. SATOR 17. Тарту 2016

Составление, техническое оформление и печать книги осуществлены при поддержке Эстонского институционального исследовательского гранта 22-5 (Религиозные и нарративные аспекты фольклора).

Оформление электронного издания осуществлено при поддержке проекта ЕККМ14-344 “Расширение областей применения и представление эстонского языка, культуры и фольклора в электронных информационных средствах".

(с) EKM Teaduskirjastus / Научное издательство ЭЛМ

(c) Авторы

(с) Анатолий Панюков \& Андрес Куперьянов 